\title{
Palaeontological analysis of Middle Miocene siltstones at Wiślica (Carpathian Foredeep, Poland)
}

\author{
Katarzyna Płonka \\ Jagiellonian University, Institute of Geological Sciences, Gronostajowa 3a, 30-387 Kraków, Poland, \\ e-mail: katarzyna.filipiak@student.uj.edu.pl
}

\begin{abstract}
Middle Miocene siltstones of the Skawina Formation that crop out at Wiślica, within the axial part of the Carpathian Foredeep in Poland, were analysed. The deposits studied contain numerous benthic and planktonic foraminifera, ostracods, echinoid spines, bryozoans, bivalves and otoliths. The fossils recognised document an early 'Badenian' (= Langhian in the Mediterranean area), or, more precisely, 'Moravian' age of the deposit. Palaeoecological analysis suggests normal-marine conditions with full salinity. The studied siltstones were deposited from middle-lower shoreface to lower-offshore, warm surface water and locally suboxic to dysoxic conditions in the sediment.
\end{abstract}

Key words: microfossils, foreland basin, foraminifera, palaeoecology.

\section{Introduction}

The research subject includes silty facies of the Middle Miocene deposits in a central part of the Carpathian Foredeep which is filled with the Miocene siliciclastic molasse and evaporites.

The Carpathian Foredeep, which is the youngest tectonic unit of Poland occupies the area between the Outer Carpathians and the Mid-Polish Uplands. Its origin is directly connected with the Outer Carpathians evolution (for details reference is made to Oszczypko, 2006). The Carpathian Foredeep basin was part of the Central Paratethys, the northern part of the disappearing Tethys Ocean (Rögl, 1998). This part of the Paratethys sea was the northernmost part of the basin. From the early Langhian (early 'Badenian') transgression to the middle Tortonian (i.e., end of the Sarmatian) age, in the basin took place a marine sedimentation (Oszczypko et al., 2006). The Carpathian Foredeep is filled with Miocene siliciclastic molasse with evaporites. Sediments near the margins, especially in the North of the basin are much more diverse. The axis of the sedimentary foredeep basin was moving from the south to the north during the Miocene time. The deposits of the Carpathian Foredeep cover different older rocks (e.g., Radwański, 1973).

The Wiślica area lies in a central part of the Carpathian Foredeep where mostly Upper Cretaceous deposits form the basement of Miocene siltstones (Łyczewska, 1972).

Miocene deposits near Wiślica were investigated by Osmólski (1963), who analysed Wawrowice, Czarkowy and Senisławice outcrops, located approximately $5 \mathrm{~km}$ southeast of Wiślica. All these outcrops document Middle Miocene deposits that overlie Cretaceous marls. Above Cretaceous marls lie Badenian mudstones, marls, gypsum and gypsum alteration products: marls, limestones, limestones with sulphates and siltstones. A stratigraphy of the region studied was determined by microfaunal analysis (Osmólski, 1963). Łyczewska (1972) described chalky marls from under-lithotamnium horizon and gypsum, anhydrite, marls, mudstones, limestones from gypsum horizon, that occur near Wiślica and Gorysławice. The Miocene deposits 
from Gorysławice near Wiślica are mentioned by Bąbel (1999) in which gypsum from Ponidzie region are investigated. New data on Neogene deposits from Busko Zdrój were presented by Paruch-Kulczycka (2015); the borehole Busko (Młyny) PIG-1 at Busko Zdrój is located about $15 \mathrm{~km}$ from Wiślica. Five foraminiferal assemblages were defined there, from the Orbulina suturalis Zone to the Anomalinoides dividens Zone.

\section{Geological setting}

The Carpathian Foredeep is part of a large sedimentary basin that extends from the Danube at Vienna (Austria) to the Iron Gate on the same river in Romania. In the west, the Carpathian Foredeep is linked with the Alpine Molasse Basin, and in the east, it passes into the Balkan foreland basin (Oszczypko et al., 2006). This foredeep developed during the Early to Middle Miocene as an asymmetric foreland basin related to the overthrusting Carpathian front; the Outer Carpathians were progressively folded towards the continental margin (e.g., Kovac et al., 1998). In the late early Burdigalian ('Ottnangian') the basin underwent desiccation. This salinity crisis was followed by the 'Ottnangian' compressive tectonic event, when the Outer Carpathian basin was folded and uplifted. During this event, the oceanic or thinned continental crust of the Outer Carpathians residual flysch basin was subducted below the overriding Carpathian orogen (Alcapa and Tisza-Dacia microplates). This was accompanied by outward overthrusting and formation of the flexural foreland basin along the moving orogenic front and partly on top of the orogenic wedge (Tomek \& Hall, 1993). The Carpathians overrode the platform and caused flexural depression on the foreland. The Carpathian Foredeep is subdivided into inner and outer parts (Oszczypko, 1998). The former comprises Lower to Middle Miocene autochthonous deposits. The Lower Miocene strata are mainly terrestrial in origin, whereas the Langhian and Serravallian ('Badenian' and 'Sarmatian') levels are marine. The lithostratigraphy of the Miocene deposits of the foreland is illustrated in Figure 1.

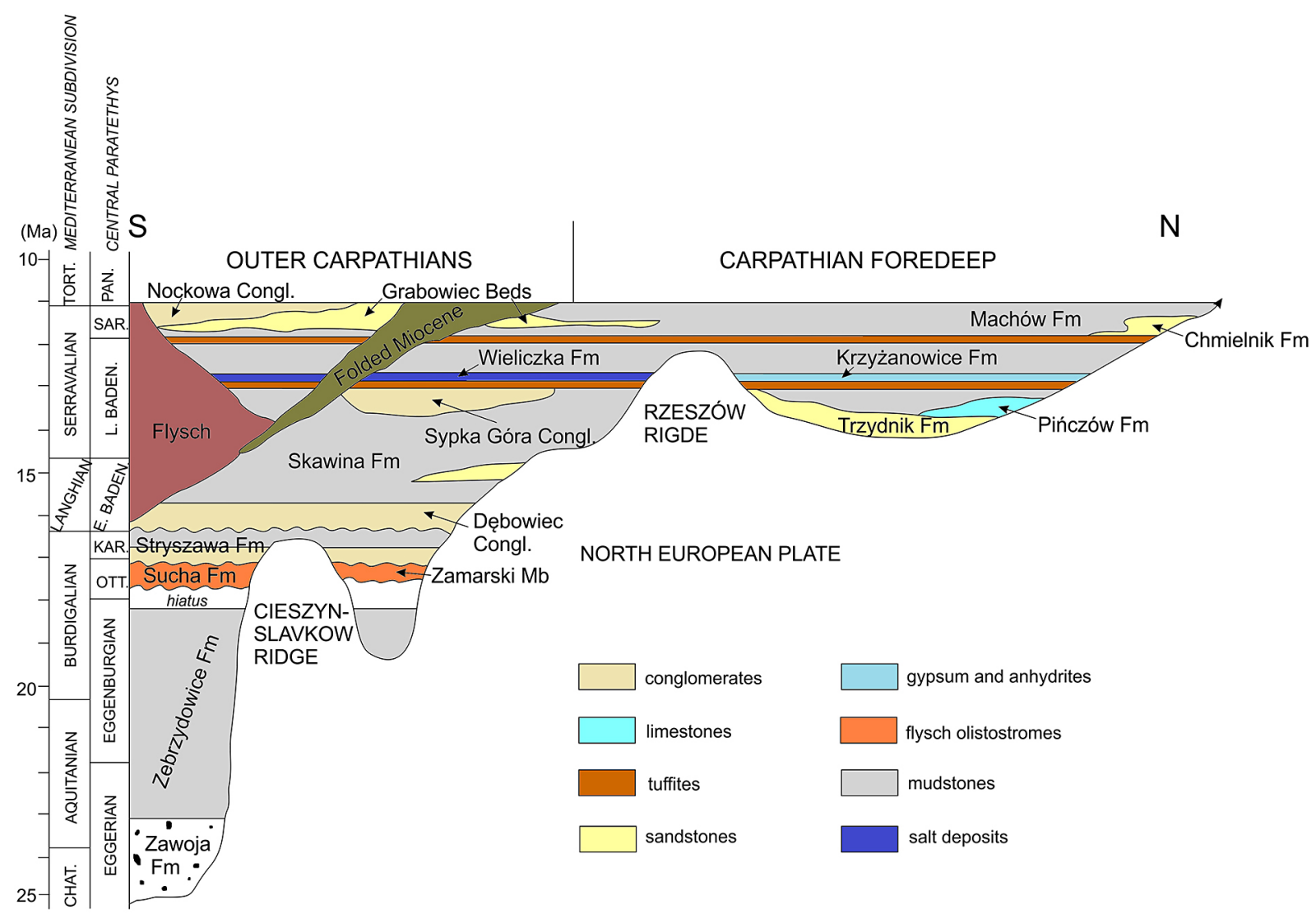

Fig. 1. Lithostratigraphy of Miocene deposits in the Carpathian Foredeep, Poland (modified after Oszczypko, 2006). Abbreviations are as follows: OTT. - 'Ottnangian'; KAR. - 'Karpatian’; E. BADEN. - early ‘Badenian’; L. BADEN. late 'Badenian'; SAR. - 'Sarmatian'; PAN. - 'Pannonian'. 
The study area lies in the marginal, northern part of the Carpathian Foredeep, close to the southern slopes of the Holy Cross Mountains (Kondracki, 2002). Detritic and calcareous deposits of Middle Miocene age formed a discontinuous belt of exposures along those mountains. South of this belt Miocene siltstones and mudstones fill almost the entire Carpathian Foredeep (Oszczypko et al., 2006).

The basement of Miocene deposits in the Wiślica area consists mostly of Upper Jurassic limestones and Upper Cretaceous marls (Łyczewska, 1972). The Miocene deposits are essentially horizontally arranged and do not show important inclination. Lithostratigraphically, the strata at Wiślica belong to the Skawina Formation (Alexandrowicz, 1963; Jasionowski, 1997). In its type area, this unit was dated on microfaunal evidence as early Langhian ('Moravian') (Euczkowska, 1964; Alexandrowicz, 1974).

\section{Outcrop studied}

Wiślica is situated in the Małopolska Upland, Nida Basin (Kondracki, 2002), about halfway between Kazimierza Wielka and Busko Zdrój (Fig. 2). The siltstone series studied is accessible near the cemetery, in the outskirts of town (GPS co-ordinates: N 5021 35,4; E 2041 5,5). Ongoing construction work for a new parking lot have led to the appearance of a near-vertical outcrop over there $(5 \mathrm{~m}$ in height, $15 \mathrm{~m}$ in length) (Fig. 3).

The deposits studied rest upon by a micritic, fossiliferous limestone the age of which is uncertain (?older Middle Miocene). The series studied in the section begins with a thin layer (thickness varies) of basal conglomerate or rudaceous rock. It is composed of pebbles derived from the basal micritic limestone. Overlying the conglomerate is a series of sandy siltstone, mixed with silty mudstone and

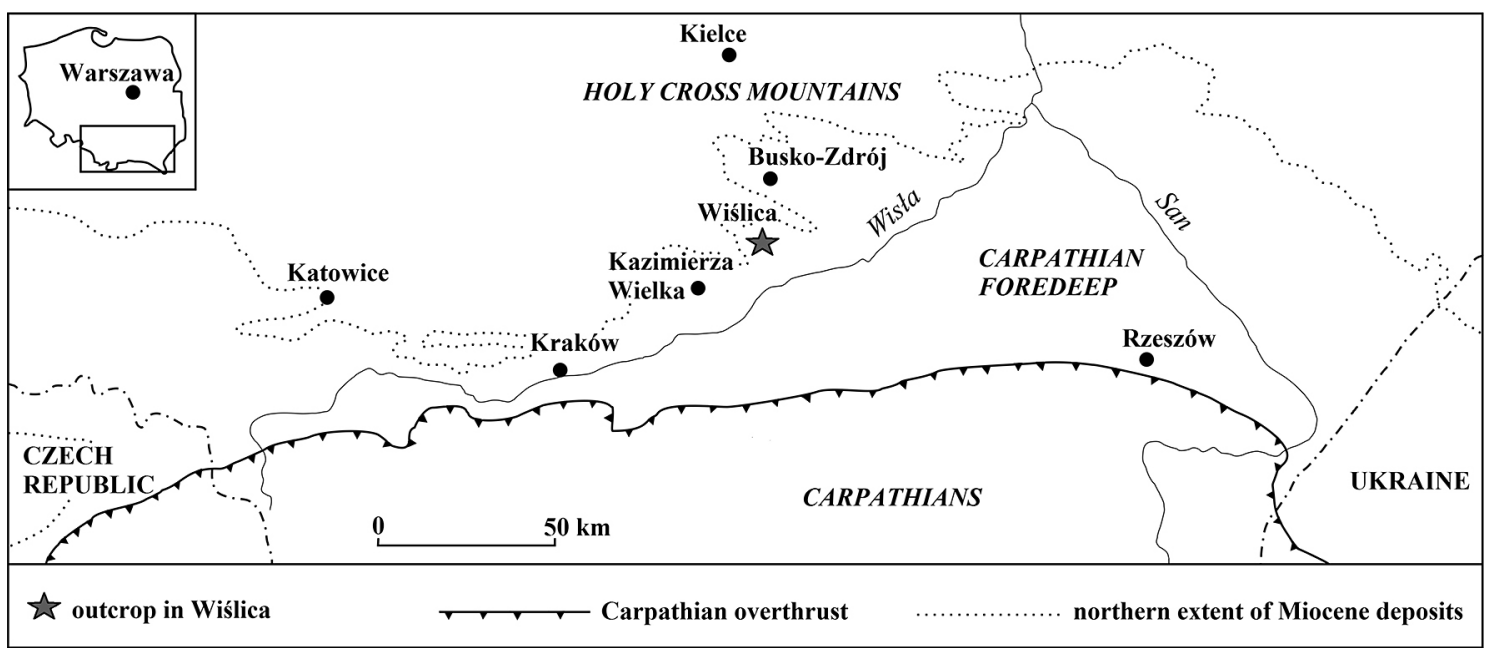

Fig. 2. Location of the outcrops at Wiślica (modified after Paruch-Kulczycka, 2015).

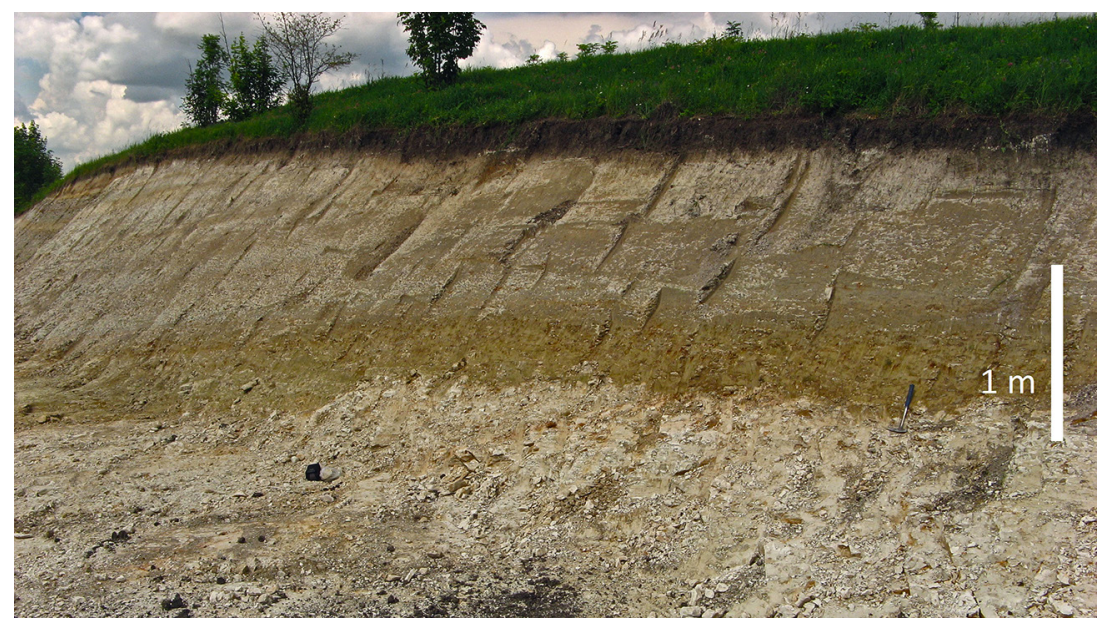

Fig. 3. The outcrop at Wiślica. 
mostly horizontally laminated silty mudstone. Between 1 and 3.5 metres above the floor, within the sandy siltstone and mudstone occur layers of calcareous siltstone (thickness from 10 to $25 \mathrm{~cm}$ ). The siltstone is brownish grey, solid, laminated and reacts to $\mathrm{HCl}(3 \%)$. The siltstone contains ferruginous nodules filled with small gypsum crystals. Some strata are filled with glauconite.

\section{Material and methods}

Fieldwork and documentation were done in the field at Wiślica. Two lithological sections were chosen and 18 samples were collected for micropalaeontological analyses. The weathering waste was firstly removed. Samples were collected respectively: 10 from the first section and 8 from the second one. Samples were collected in $30 \mathrm{~cm}$ intervals in both cases. Moreover, macrofossils and lithological samples of the siltstone basement were taken.

The samples, each weighing 400 grams, were disintegrated with use of standard method of clastation using Glaubert's salt and sludging. Microfossils gained in the process were identified and photographed using scanning electron microscope (SEM) in the laboratory at the Institute of Geological Sciences (Jagiellonian University, Kraków - HITACHI S-4700 microscope with NORAN Vantage microanalysis system). Fossil identification was done with the use of the following papers: Łuczkowska (1964), Szczechura (1982), Loeblich \& Tappan (1987), Malinowska \& Piwocki (1996), Cicha et al. (1998), Rögl \& Spezzaferri (2003) BouDagher-Fadel (2013) and Paruch-Kulczycka (2015).

\section{Results and discussion}

From the sandy siltstone and siltstone a few bivalves (Fig. 4) were collected; these comprise oysters (Pycnodonte sp.), pectinids (Amussium sp., Aequipecten cf. macrotis, Pecten besseri, Chlamys cf. scabrella), nuculids (Nucula nucleus) and myoids (Glossus humanus). In view of the fact that shells were mostly crushed, identification was not straightforward. Microfossils in these samples are represented mainly by planktonic and calcareous benthic foraminifera; agglutinated species are very rare. Figures 5 to 9 illustrate all foraminifera taxa identified. In addition, echinoid spines, bryozoans, ostracods and remains of Osteichthyes (bony fish), in particular otoliths and, rarely, teeth were recognised in the material analysed (see Fig. 10 for a selection).
The pectinids Chlamys cf. scabrella, Pecten besseri, Amussium sp. and Aequipecten cf. macrotis date the siltstone at Wiślica as 'Badenian' (Studencka, 1986; Mandic, 2004). In addition, the following foraminiferal taxa have a limited range (early Langhian = early 'Badenian' - Moravian; see Cicha et al., 1998) and are age specific: Vaginulina legumen, Uvigerina macrocarinata, Otrhomorphina columella, Orbulina suturalis, Lenticulina echinata, Bulimina angusta and Amphicoryna ?scalaroides. Brief descriptions of these taxa can be found in the Appendix. The large number of specimens of the early Langhian (early 'Badenian') index planktonic foram Orbulina suturalis also dates the siltstone as Langhian ('Moravian'; see Łuczkowska, 1964, 1978). On the basis of intense occurrence of Globigerina sp., Orbulina suturalis, Marginulina hirsuta, Vaginulina legumen, Uvigerina sp., Nodosaria sp., Dentalina sp. and Bulimina sp. the siltstone at Wiślica can be classified as the Orbulina suturalis Zone (Łuczkowska, 1964, 1978). This zone matches previous foraminiferal zones division IIA and IIB that are characteristic of the Miocene (Alexandrowicz, 1963), which also confirms the early Langhian ('Moravian') age of the siltstone (Olszewska et al., 1996; Olszewska, 1999). However, it should be noted that biozonal subdivisions were based on intense occurrence of species groups, not always with a predominance of one of the species. Because of that, classification could be subjective. Also the same groups of species sometimes occur in more than one biozone. Biostratigraphical units should be then treated rather as ecozones, not always strictly as classic biohorizons.

The age of the micritic limestone that underlies the siltstone studied was not specified because of a lack of diagnostic fossils. Presumably, the limestone is a diagenetic form of the Cretaceous rocks or an older Miocene member of deposits. The conglomerate is basal and contains oyster fossils typical of that region of the Miocene deposits (Malinowska \& Piwocki, 1996). This suggests that the basal limestone formed prior to the early Langhian (early 'Badenian') transgression (Radwański, 1968, 1973). The abundance and diversity of microfossils in investigated siltstone at Wiślica suggest advantageous environmental conditions for many groups of organisms. Microfossils are well preserved, calcareous foraminiferal tests are complete and there are no bioerosional marks in the deposit. The presence of pectinids, echinoid and planktonic foraminifera points to normal marine environmental conditions (e.g., Szczechura, 1982; Studencka, 1999), as do benthic foraminifera, including Fursenkoina sp. and Nonion sp. (Murray, 1991). Benthic foraminifera are mainly infaunal and epifaunal detritivores 


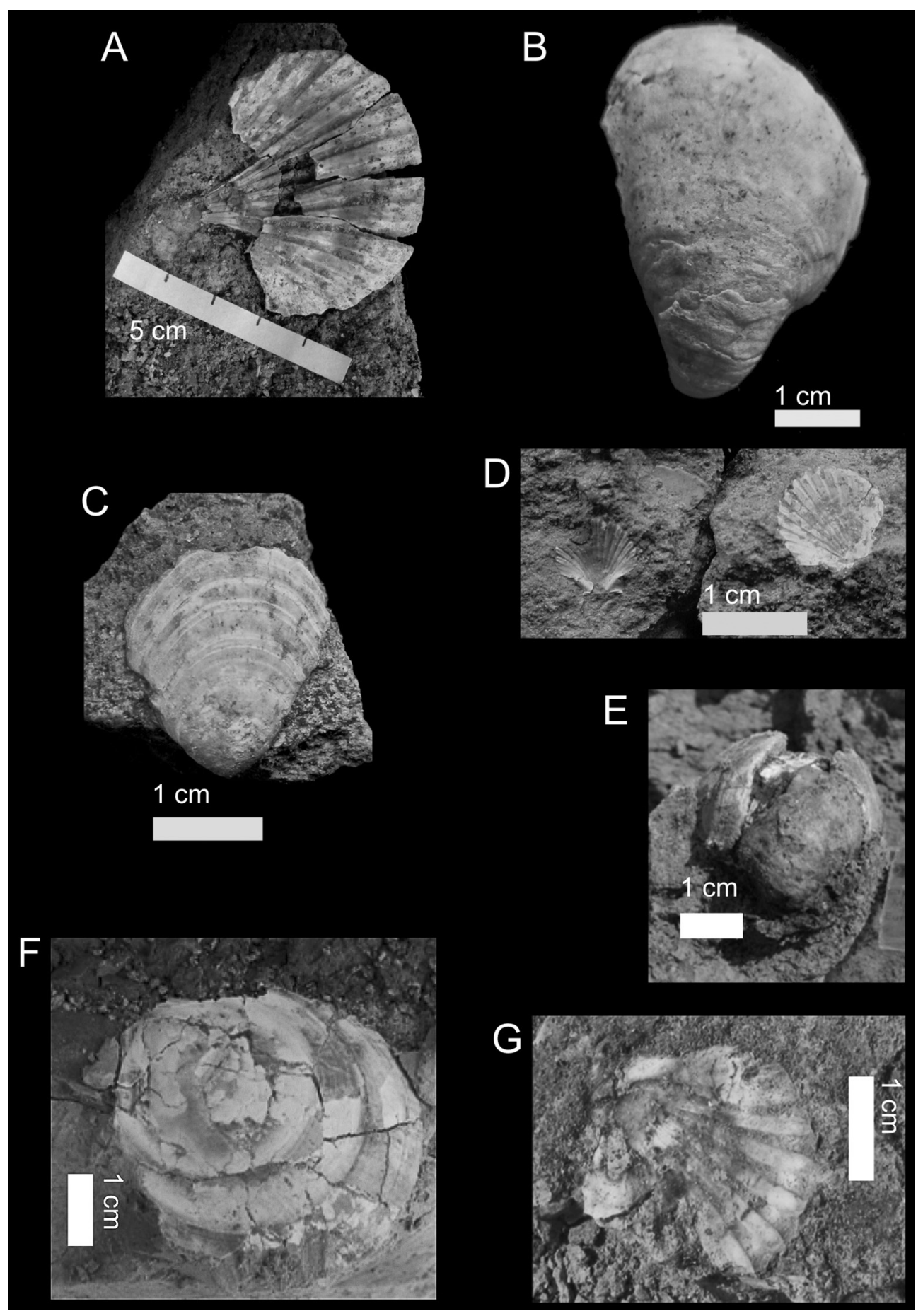

Fig. 4. Bivalves from the Wiślica outcrop. A - Chlamys cf. scabrella; B - Glossus humanus; C - Nucula nucleus; D - Pecten besseri; E - Pycnodonte sp.; F - Amussium sp.; G -Aequipecten cf. macrotis. 

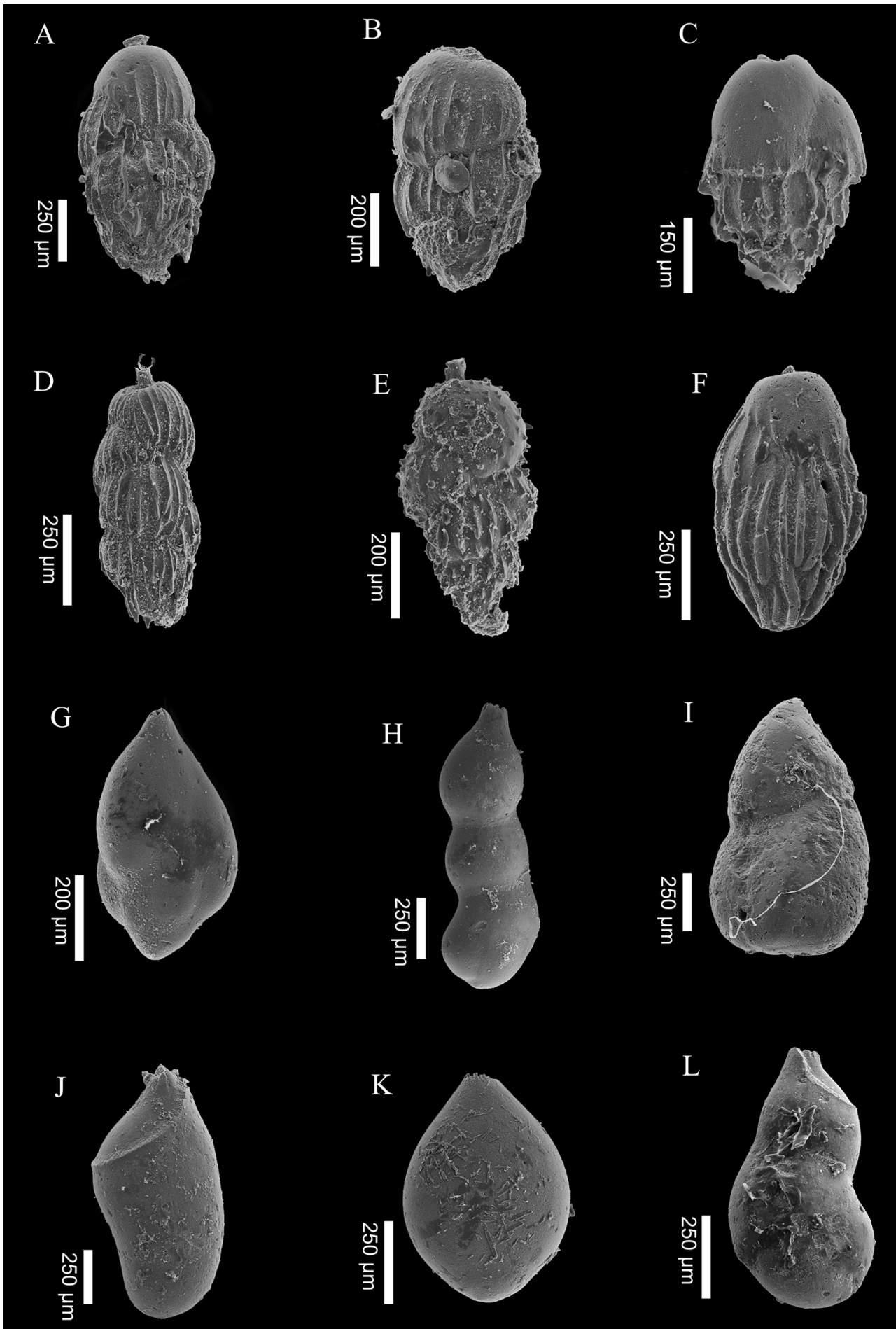

Fig. 5. Benthic foraminifera from the Wiślica outcrop. A, B - Uvigerina bellicostata; C -Bulimina striata; D - Uvigerina costai; E - Uvigerina sp.; F - Uvigerina macrocarinata; G - Guttulina communis; H - Vaginulinopsis pedum; I - Guttulina sp.; J - Vagulinopsis pedum; K - Globulina gibba; L - Dimorphina akneriana. 

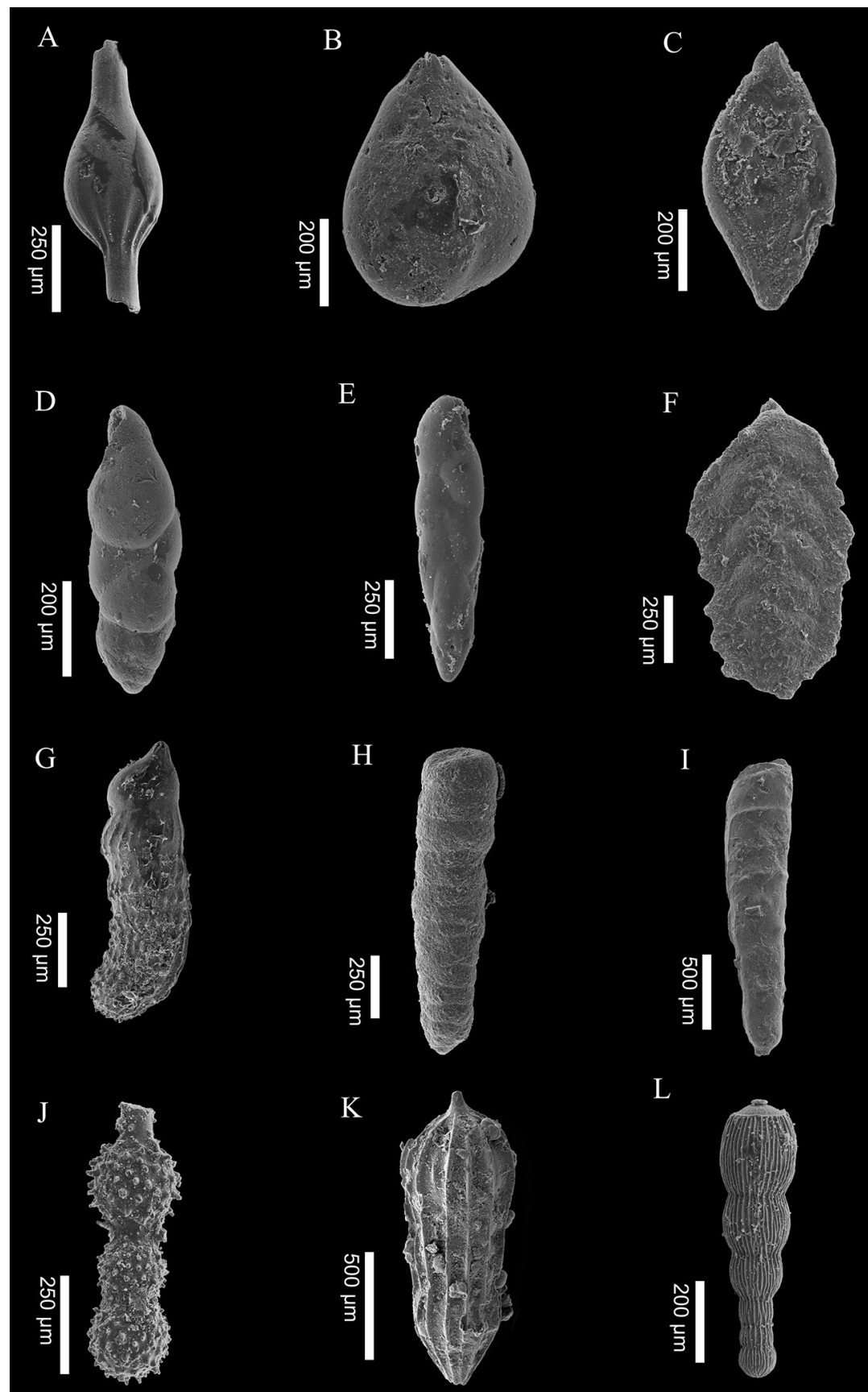

$\mathrm{K}$

$\mathrm{L}$

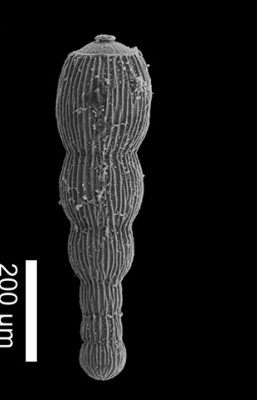

Fig. 6. Additional benthic foraminifera from the Wiślica outcrop. A - Grigelis semirugosus; B - Guttulina communis; C Spiroculina sp.; D - Bulimina angusta; E - Fursenkoina schreibersiana; F - Spirorutilus carinatus; G - Marginulina hirsuta; H - Martinottiella communis; I - Vaginulina legumen; J - Nodosaria hispida; K - Amphicoryna? scalaroides; L - Nodosaria ?badenensis. 

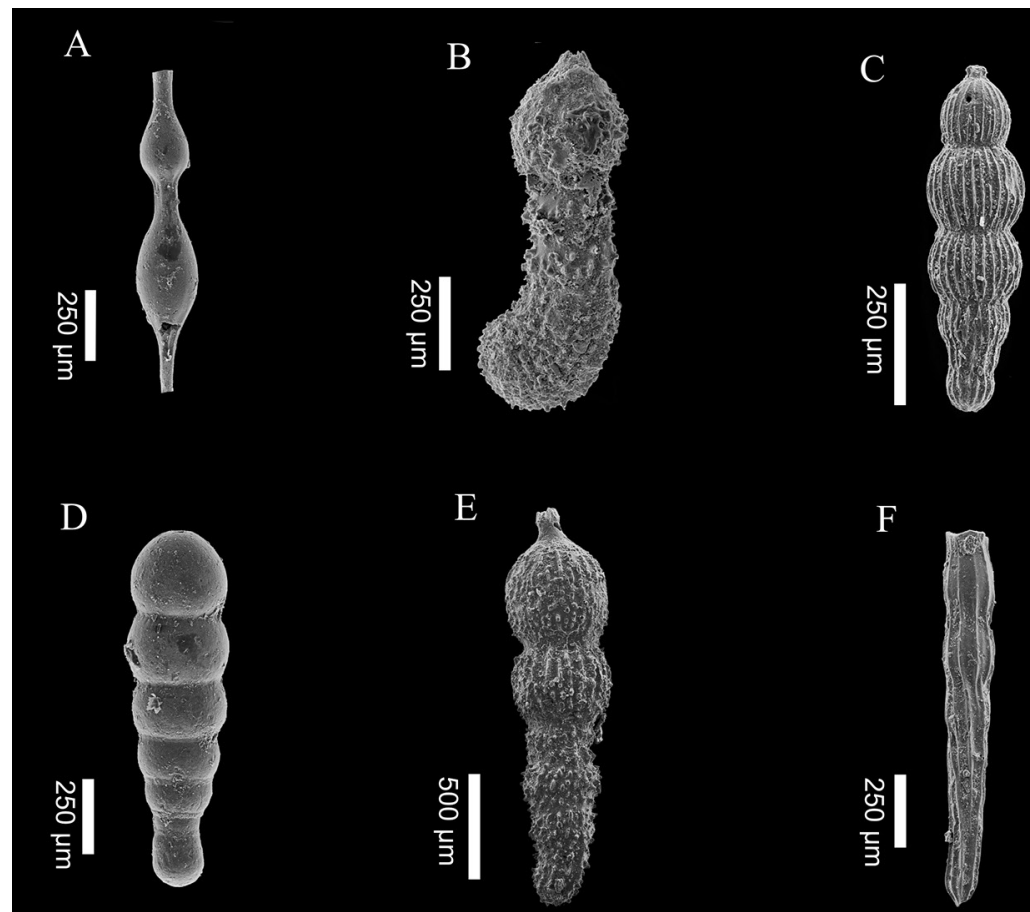

G
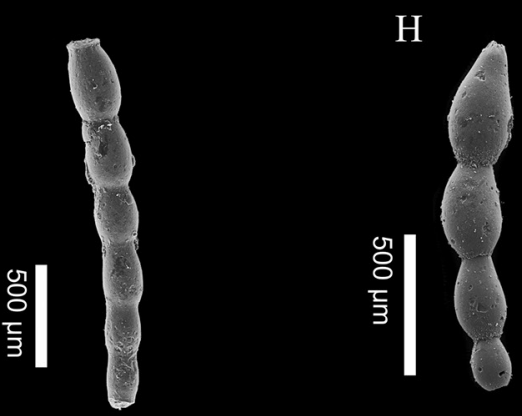

I
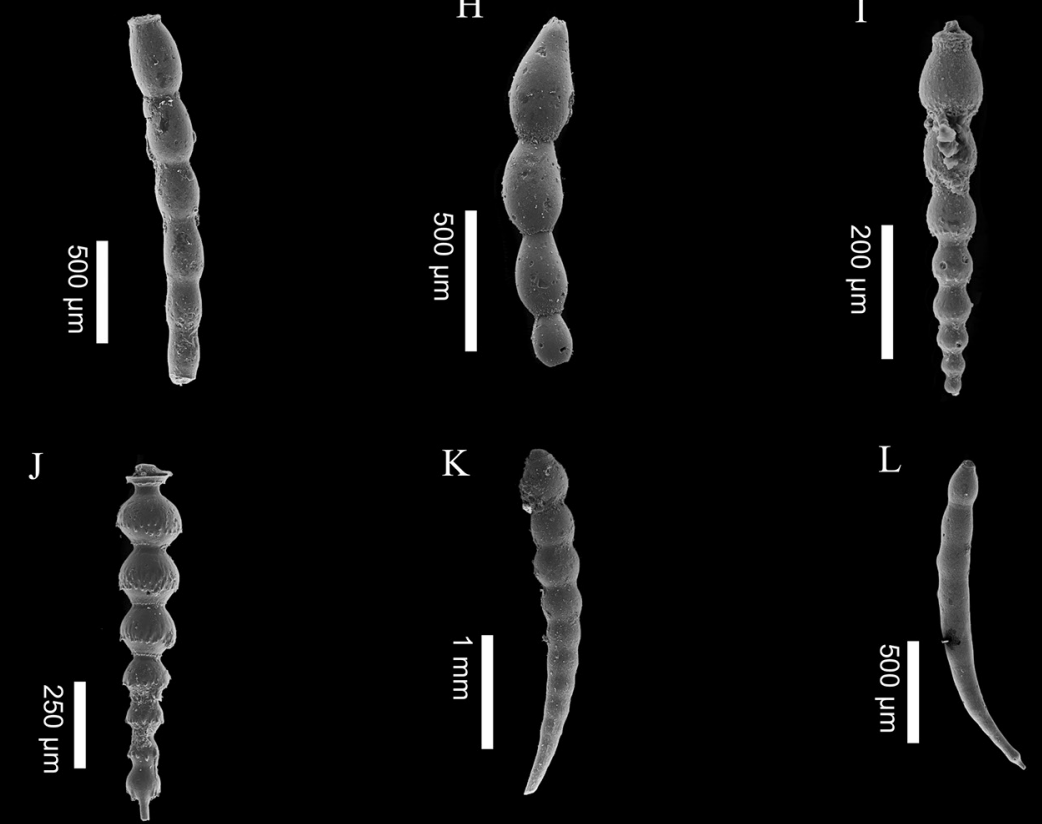

Fig. 7. Additional benthic foraminifera from the Wiślica outcrop. A - Grigelis pyrula; B, E - Marginulina hirsuta; C - Orthomorphina columella; D - Nodosarella rotundata; F - Dentalina acuta; G - Laevidentalina inornata; H - Nodosaria soluta; I - Stilostomella? consobrina; J - Stilostomella adolphina; K, L - Laevidentalina elegans. 


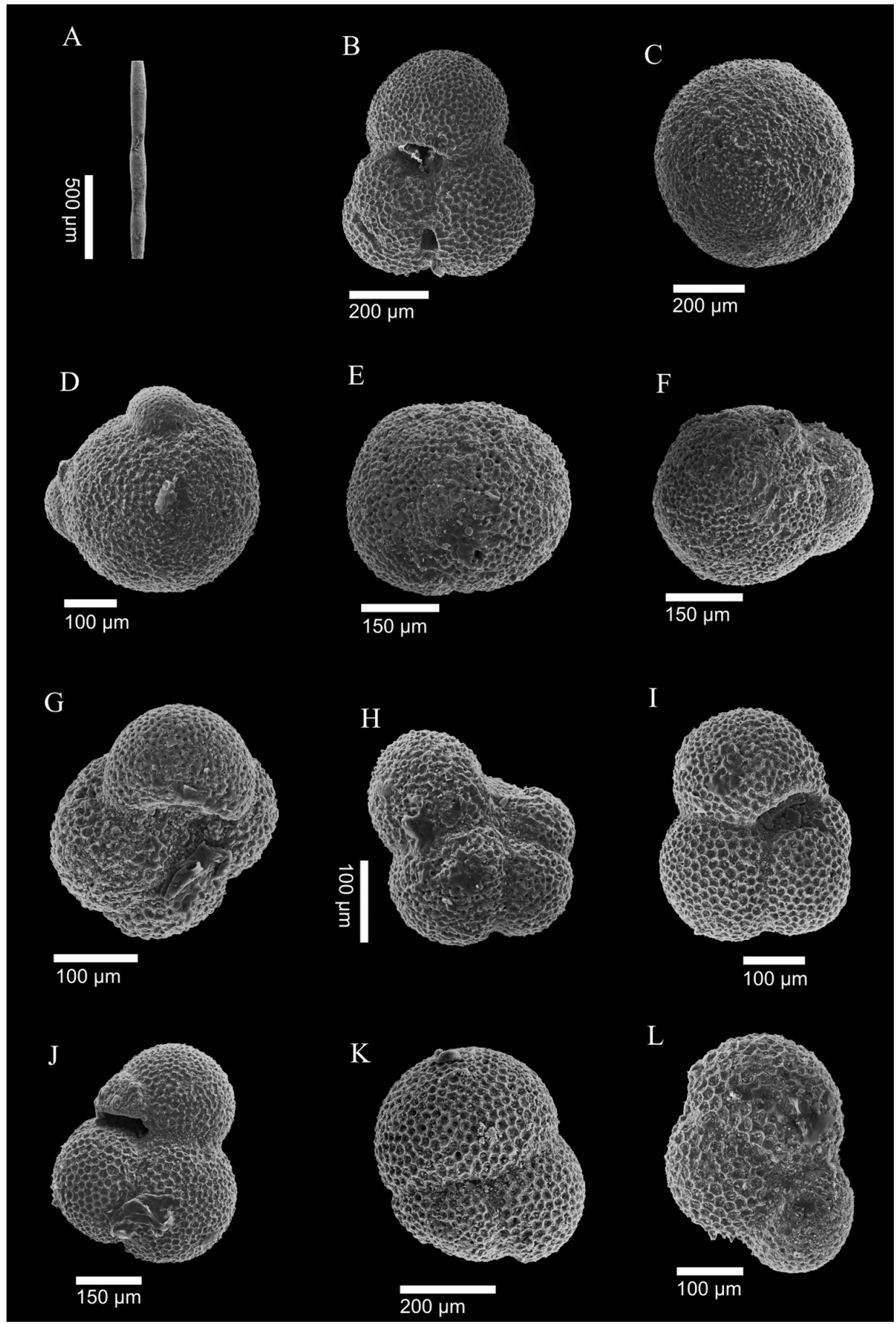

Fig. 8. Benthic (B) and planktonic (P) foraminifera from the Wiślica outcrop. A - Scallopostoma ovicula (B); B - Globigerinoides ?quadrilobatus $(\mathrm{P})$; C, D - Orbulina suturalis $(\mathrm{P}) ; \mathbf{E}, \mathbf{F}-$ Orbulina bilobata $(\mathrm{P}) ; \mathrm{G}$ - Neogloboquadrina sp. $(\mathrm{P}) ; \mathrm{H}$ - Tenuitella ?brevispira (P); I, J - Globigerinoides sp. (P); K, L - Globigerina sp. (P). 


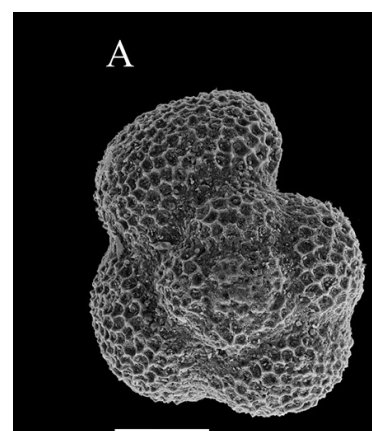

B

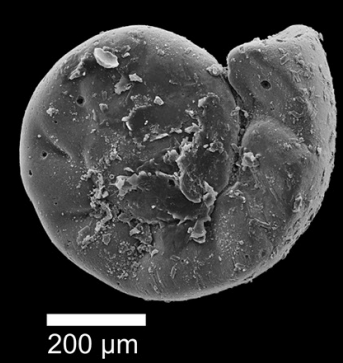

E

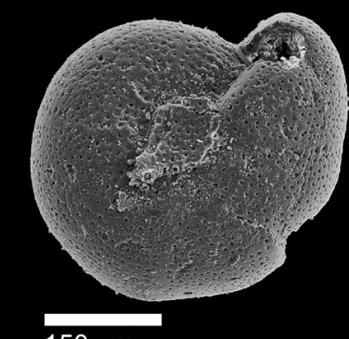

$150 \mu \mathrm{m}$

G

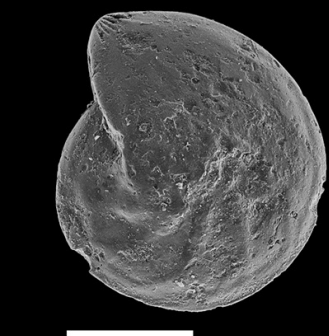

$500 \mu \mathrm{m}$

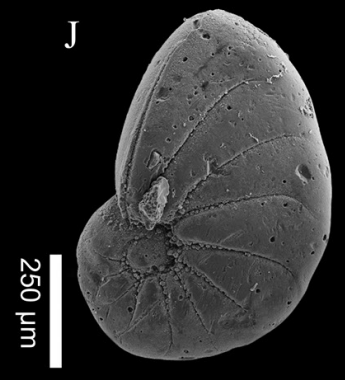

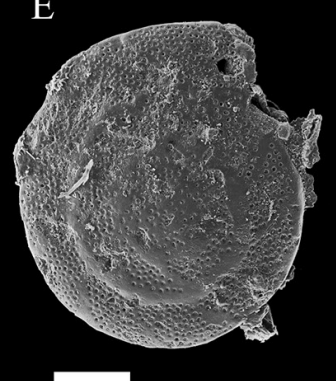

$250 \mu \mathrm{m}$

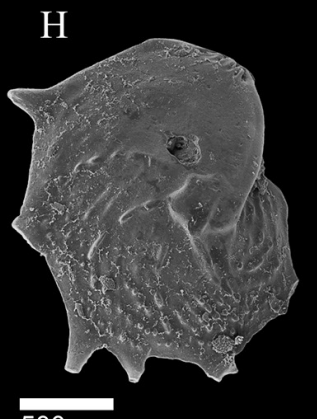

$500 \mu \mathrm{m}$

K

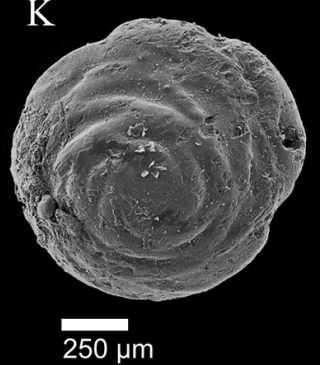

C

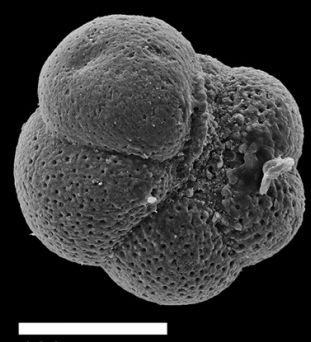

$100 \mu \mathrm{m}$

F

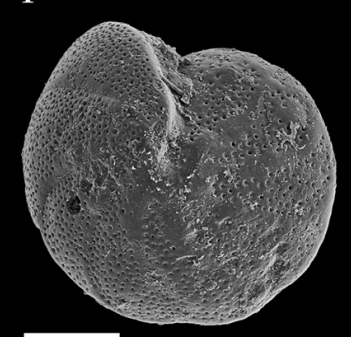

$250 \mu \mathrm{m}$

I

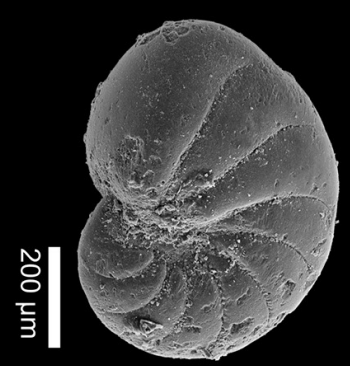

L

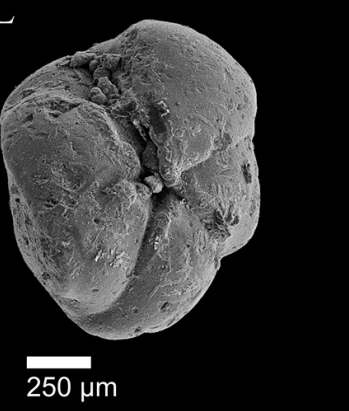

Fig. 9. Additional planktonic $(\mathrm{P})$ and benthic $(\mathrm{N})$ foraminifera from the Wiślica outcrop. A - Dentoglobigerina globosa (P); C - Globoconella bykovae (P); B - Hansenisca soldani (B); D - Melonis pompilioides (B); E, F - Heterolepa dutemplei (B); G - Lenticulina inornata (B); H - Lenticulina echinata (B); I, J - Nonion commune (B); K, L - Neoponides schreibersi (B). 


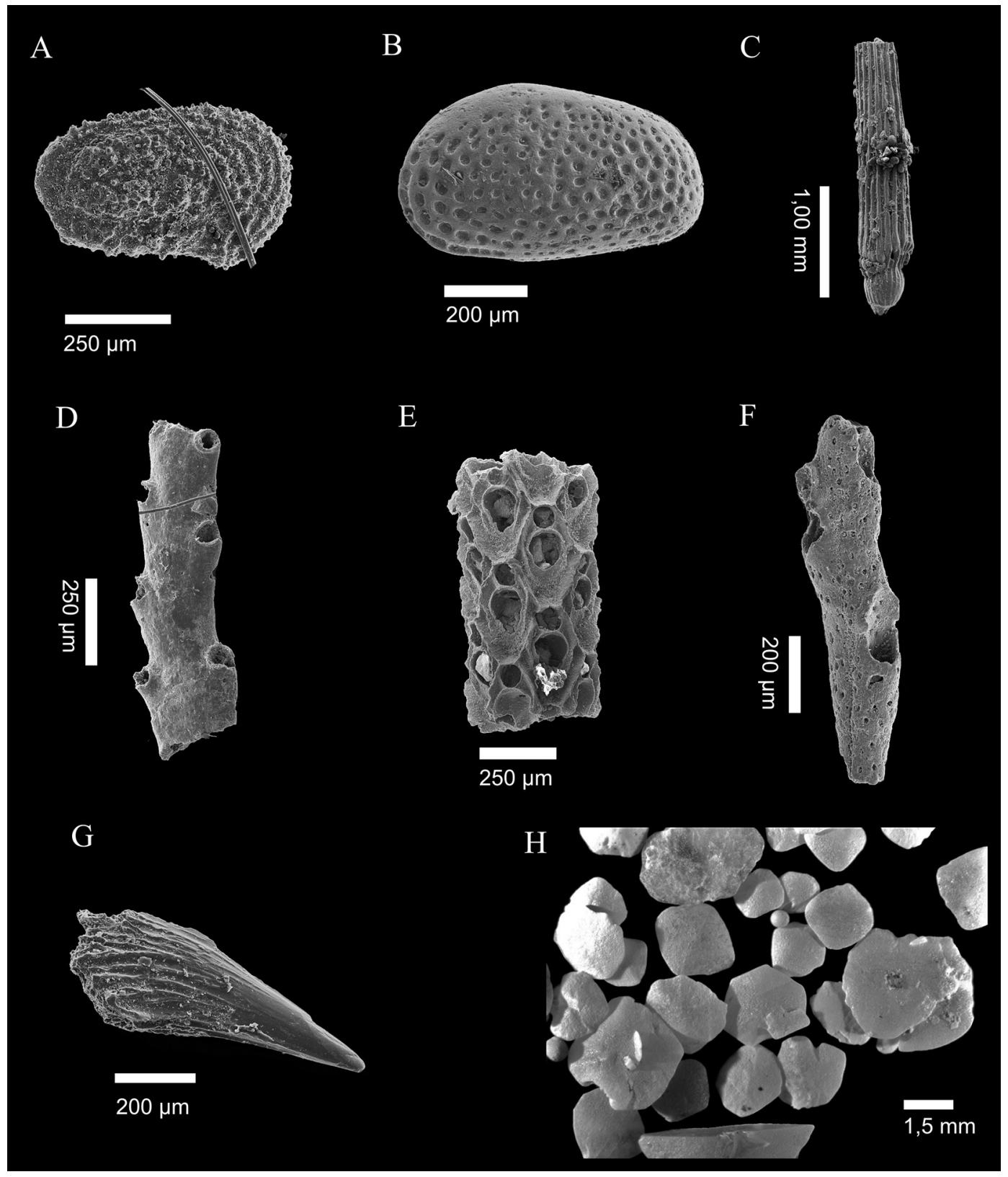

Fig. 10. Other microfossils from the Wiślica outcrop. A, B - ostracods; C - echinoid spine; D-F - bryozoans; G - fish tooth; $\mathbf{H}$ - fish otoliths. 
which prefer silty or fine-grained sandy settings and low temperatures (Murray, 1991). The presence of the genera Fursenkoina, Heterolepa, Melonis, Nonion, Uvigerina, Chilostomella, Lenticulina, Martinotiella and Stilostomella points to deposition in an outer (middle-lower shoreface) to inner shelf (lower-offshore) (Murray, 2006). However, these depositional zones should be considered only in a depth sense in scarcely few hundred metres wide part of the Paratethys. The presence of Lenticulina, Nodosaria, Laevidentalina, Bulimina, Uvigerina and Stilostomella, suggests locally suboxic conditions in the deposit. But, two other facts point also to locally dysoxic conditions on the bottom. Firstly, identified in samples Chilostomella sp., Fursenkoina sp. and suboxic species which tolerate lower oxygen content in the deposit as well. Secondly, occurrence of glauconite in some samples (Kaiho, 1994). Planktonic foraminifera are represented mainly by cosmopolitan genera such as Orbulina, Globigerinoides and Globigerina (BouDagher-Fadel, 2013). The predominance and large test size of thermophilic genera such as Orbulina and Globigerinoides and the low number of specimens of Globigerina, which prefers a cold environment, suggests high temperature of surface water (Bicchi et al., 2003). Orbulina and Globigerinella are characteristic of the outer neritic zone, while Globigerina occurs in inner neritic settings and Globigerinoides in both settings (BouDagher-Fadel, 2013).

\section{Conclusions}

The siltstone at Wiślica belongs to the Skawina Formation.

Deposits studied represent the traditional Orbulina suturalis Zone. Biostratigraphical units should be treated as ecozones, rather than classic biohorizons. This is caused by occurrence of numerous index forams taxa within many deposits varying in age. Moreover, some zones have been allocated based on numerous occurrence instead of more objective FAD.

Micropalaeontological analysis has revealed that the siltstone can be dated as early Langhian (early 'Badenian', 'Moravian').

Microfossils from Wiślica are very well preserved and no damaging taphonomic factors had an influence on them, which makes palaeoenvironmental analysis more representative of a true biocoenosis. Macro- and microfossils from Wiślica are indicative of normal marine conditions.

Benthic foraminifera recorded illustrate deposition on outer (middle-lower shoreface) to inner shelf (lower-offshore), under low water tempera- ture at the bottom. Planktonic foraminifera point to neritic outer to inner zone and suggest high temperature of surface water. A palaeoecological analysis has revealed local suboxic to dysoxic conditions on the sea floor during deposition.

\section{Acknowledgements}

This work forms part of my MSc thesis. I am grateful to Dr Michał Stachacz (Jagiellonian University, Kraków) for help, valuable suggestions, constructive criticism and correction of an earlier typescript, to Prof. Adam Gasiński (Jagiellonian University, Kraków) for valuable consultation, to Joanna Urbaniak MSc, Anita Jazowska MSc and Adam Wierzbicki MSc, who supported me during field and laboratory work. Finally, I thank the journal reviewers for insightful comments and suggestions.

\section{References}

Alexandrowicz, S.W., 1963. Zarys stratygrafii miocenu okolic Krakowa [Outline of Miocene stratigraphy in Cracow area]. Sprawozdanie z Posiedzenia Komisji Nauk Geologicznych PAN Oddziat w Krakowie 7-12, 520-523.

Alexandrowicz, S.W., 1974. Profil wzorcowy warstw skawińskich (Badenian) w Skawinie koło Krakowa [Stratotype section of Skawina Formation (Badenian) in Skawina near Kraków]. Sprawozdanie z Posiedzenia Komisji Naukowych PAN Oddział w Krakowie 17, 194195.

Bąbel, M., 1999. Facies and depositional environments of the Nida Gypsum deposits (Middle Miocene, Carpathian Foredeep, southern Poland). Geological Quarterly 43, 405-428.

Bicchi, E., Ferrero, E. \& Gonera, M., 2003. Paleoclimatic interpretation based on Middle Miocene planktonic Foraminifera: the Silesia Basin (Paratethys) and Monferrato (Tethys) records. Palaeogeography Palaeoclimatology Palaeoecology 196, 265-303.

BouDagher-Fadel, M.K., 2013. Biostratigraphic and geological significance of planktonic foraminirefa. OVPR UCL, London, 287 pp.

Cicha, I., Rögl, F., Rupp, C. \& Ctyroka, J., 1998. Oligocene-Miocene foraminifera of the Central Parathetys. Abhandlungen der Senckenbergischen Naturforschenden Gesellschaft 549, 325 pp.

Jasionowski, M., 1997. Zarys litostratygrafii osadów mioceńskich wschodniej części zapadliska przedkarpackiego [Sketch of Miocene deposits lithostratigraphy in eastern part of the Carpathian Foredeep in Poland]. Biuletyn Państwowego Instytutu Geologicznego 375, 43-60.

Kaiho, K., 1994. Benthic foraminiferal dissolved-oxygen index and dissolved oxygen levels in the modern ocean. Geology 22, 719-722. 
Kondracki, J., 2002. Geografia regionalna Polski [Regional geography of Poland]. Wydawnictwo Naukowe PWN, Warszawa, $444 \mathrm{pp}$.

Kovac, M., Nagymarosy, A., Oszczypko, N., Slaczka, A., Csontos, L., Marunteanu, M., Matenco, L. \& Marton, E. 1998. Palinspastic reconstruction of the CarpathianPannonian region during the Miocene. [In:] M. Rakus (Ed.), Geodynamic development of the Western Carpathians: Bratislava. Slovak Geological Survey, 189-217.

Loeblich, A.R., Jr. \& Tappan, H., 1987. Foraminiferal genera and their classification. London Chapman \& Hall (Van Nostrand Reinhold Comp., 1988), vol. 1 (970 pp.), vol. 2 (212 pp.).

Łuczkowska, E., 1964. Stratygrafia mikropaleontologiczna miocenu w rejonie Tarnobrzeg-Chmielnik [Micropalaeontological stratigraphy of the Miocene deposits in Tarnobrzeg-Chmielnik area]. Komisja Nauk Geologicznych, Prace Geologiczne 20, 65 pp.

Łuczkowska, E., 1978. Holostratotypen der Unterstufen des Badenian. Wielicien. [In:] E. Brestenská (Ed.), Chronostratigraphie und Neostratotypen: Miözan der Zentralen Paratethys. Bd. 6. $M_{4}$ Badenian. Veda, Bratislava, 148-151.

Łyczewska, J., 1972. Objaśnienia do szczegótowej mapy geologicznej Polski w skali 1:50000, arkusz Busko Zdrój [Explanations to the detailed geological map of Poland 1:50000, sheet Busko Zdrój]. Państwowy Instytut Geologiczny, Warszawa, 58 pp.

Malinowska, L., \& Piwocki, M., 1996, Budowa geologiczna Polski. T. 3. Atlas skamieniałości przewodnich i charakterystycznych. Cz. 3a [Geology of Poland. Vol. 3. Atlas of index and characteristic fossils. Part 3a]. Polska Agencja Ekologiczna, Warszawa, 1074 pp.

Mandic, O., 2004. Pectenid bivalves from Grund Formation (Lower Badenian, Middle Miocene, Alpine-Carpathian Foredeep) - taxonomic revision and stratigraphic significance. Geologica Carpathica 55, 129-146.

Murray, J.W., 1991. Ecology and palaeoecology of benthic foraminifera. Longman, Avon, $397 \mathrm{pp}$.

Murray, J.W., 2006. Ecology and applications of benthic foraminifera. Cambridge University Press, Cambridge, 426 pp.

Olszewska, B., 1999. Biostratygrafia neogenu zapadliska przedkarpackiego w świetle nowych danych mikropaleontologicznych [Biostratigraphy of Neogene in the Carpathian Foredeep in the light of new micropalaeontological data in Polish]. Prace Panstwowego Instytutu Geologicznego 168, 9-28.

Olszewska, B., Piwocki, M. \& Ziembińska-Tworzydło, M., 1996. Korelacja biostratygraficzna neogenu Polski z innymi obszarami [Biostratigraphical correlation of Polish Neogene deposits with other regions]. [In]: L. Malinowska \& M. Piwocki (Eds), Budowa Geologiczna Polski. T. 3. Atlas skamieniatości przewodnich i charakterystycznych. Cz. 3a. Polska Agencja Ekologiczna, Warszawa, 502-517.
Osmólski, T., 1963. Miocen w widłach rzek Wisły i Nidy oraz jego siarkonośność [Miocene deposits within the fork of the Nida and the Vistula Rivers, and their sulphur contents]. Geological Quarterly 7, 337-351.

Oszczypko, N., 1998. The Western Carpathian Foredeep - Development of the foreland basin in front of the accretionary wedge and its burial history (Poland). Geologica Carpathica 49, 1-18.

Oszczypko, N., 2006. Powstanie i rozwój polskiej części zapadliska przedkarpackiego [Development of the Polish sector of the Carpathian Foredeep]. Przeglad Geologiczny 54, 396-403.

Oszczypko, N., Krzywiec, P., Popadyuk, I. \& Peryt, T., 2006. Carpathian Foredeep Basin (Poland and Ukraine): Its Sedimentary, Structural, and Geodynamic Evolution. [In]: J. Golonka \& F.J. Picha (Eds), The Carpathians and their foreland: Geology and hydrocarbon resources. AAPG Memoir 84, 293-350.

Paruch-Kulczycka, J., 2015. Foraminiferal biostratigraphy of the Miocene deposits from the Busko (Młyny) PIG1 and Kazimierza Wielka (Donosy) PIG-1 boreholes (northern part of the Carpathian Foredeep). Biuletyn Państwowego Instytutu Geologicznego 461, 115-132.

Radwański, A., 1968. Transgresja dolnego tortonu na obszarze Wyżyny Miechowskiej i Krakowskiej [Lower Tortonian transgression onto the Miechów and Cracow Uplands]. Acta Geologica Polonica 18, 367-445.

Radwański, A., 1973. Transgresja dolnego tortonu na południowo-wschodnich i wschodnich stokach Gór Świętokrzyskich [Lower Tortonian transgression onto the south-eastern and eastern slopes of the Holy Cross Mts]. Acta Geologica Polonica 23, 375-434.

Rögl, F., 1998. Palaeogeographic Considerations for Mediterranean and Paratethys Seaways (Oligocene to Miocene). Annalen Naturhistorishen Museums in Wien 99A, 279-310.

Rögl, F. \& Spezzaferri, S., 2003. Foraminiferal paleoecology and biostratigraphy of the Mühlbach section (Gaindorf Formation, Lower Badenian). Annalen des Naturhistorischen Museum in Wien 104A, 23-75.

Studencka, B., 1986. Bivalves from the Badenian (Middle Miocene) marine sandy facies of southern Poland. Palaeontologica Polonica 47, 3-128.

Studencka, B., 1999. Remarks on Miocene bivalve zonation in the Polish part of the Carpathian Foredeep. Geological Quarterly 43, 467-477.

Szczechura, J., 1982. Middle Miocene foraminiferal biochronology and ecology of SE Poland. Acta Palaeontologica Polonica 27, 1-44.

Tomek, C. \& Hall, J., 1993. Subducted continental margin imaged in the Carpathians of Czechoslovakia. Geology $21,535-538$.

Manuscript received: 21 June 2016 Revision accepted: 2 March 2017 


\section{Appendix}

Brief descriptions of biostratigraphically significant species

Family Vaginulinidae Reuss, 1860

Genus Amphicoryna Schlumberger, 1881

Amphicoryna scalaroides (ten Dam \& Reinhold, 1942)

(Fig. $6 \mathrm{~K}$ )

1942 Nodosaria scalaroides A. ten Dam, T. Reinhold, p. 64 , pl. 4, fig. 5.

Material: About 20 specimens.

Description: Uniserial, elongate test consisting of three chambers. First chamber smallest and apiculate; second chamber larger and third largest with neck at terminal aperture. Chamber walls with costae perpendicular to sutures and linked over entire test. Sutures slightly depressed and indistinct.

Regional occurrence: Poland: Upper Silesia, margins of Holy Cross Mountains - 'Badenian' (Langhian); the Netherlands - Middle Miocene.

Genus Lenticulina Lamarck, 1804

Lenticulina echinata (d'Orbigny, 1846)

(Fig. $9 \mathrm{H}$ )

1846 Robulina echinata A. d'Orbigny, p. 100, pl. 4, figs. 21, 22.

Description: Lenticular and planispiral; raised. Convex sutures raised and curved. Central umbo, irregular. Six spines, mostly broken, along edge of test. 5-6 chambers in ultimate whorl. Test surface covered by nodes and ribs.

Regional occurrence: Poland: Carpathian Foredeep, margins of Holy Cross Mountains, Upper Silesia 'Moravian' (Langhian); western Europe - Miocene.

Family Globigerinidae Carpenter, Parker \& Jones, 1862

Genus Candorbulina Jedlitschka, 1934

Candorbulina suturalis (Brönnimann, 1951)

(Fig. 8 C-D)

1951 Orbulina suturalis P. Brönnimann, p. 271, pl. 31, Fig. 9.

Material: About 150 specimens.

Description: Test spherical, early stage trochospiral. Final chamber much larger, spherical and enveloping umbilical side of trochospiral part. Trochospiral coil penetrates surface or slightly protrudes above spherical chamber. Sutures slightly depressed. Sutural supplementary openings in ultimate chamber.
Regional occurrence: Poland: lowlands - early ‘Badenian' (Langhian), Carpathian Foredeep - 'Badenian' (Langhian); Central Paratethys - 'Badenian' (Langhian); Tethys - Langhian-Messinian.

Family Buliminidae Jones, 1875

Genus Bulimina d'Orbigny, 1836

Bulimina angusta Łuczkowska, 1967

(Fig. 6 D)

1967 Bulimina angusta E. Łuczkowska, p. 237, pl. 8, figs. 6-9; text-fig. 3.

Material: About 30 specimens.

Description: Test elongated; convex, rounded chambers. Sutures depressed. Final chambers biserial, but initial chambers probably triserial (noted in only few specimens; many specimens have this part poorly preserved). Test surface smooth, lacking ornamentation. Some specimens perforate.

Regional occurrence: Poland: margins of Holy Cross Mountains - 'Moravian' (Langhian).

Family Uvigerinidae Haeckel, 1894

Genus Uvigerina d'Orbigny, 1826

Uvigerina macrocarinata Papp \& Turnovsky, 1953

(Fig. 5 F)

1953 Uvigerina macrocarinata Papp \& Turnovsky, p. 123, pl. 5/B, figs. 1-3.

Material: About 20 specimens.

Description: Test stout, rounded in initial part. Main stage ornamented with distinct costae extending across sutures. Initial part of costae shaped as blunt spine. Costae end at base of ultimate chamber smooth. Neck short and depressed at base. Regional occurrence: Central Paratethys - early ‘Badenian' (Langhian).

Family Vaginulinidae Reuss, 1860

Genus Vaginulina d'Orbigny, 1826

Vaginulina legumen (Linnaeus, 1758)

(Fig. 6 I)

1758 Nautilus legumen Linnaeus, p. 711, no. 248.

Material: About 10 specimens.Description: Test elongate, uniserial, rectilinear to arcuate, laterally compressed. Dorsal margin commonly straight, ventral margin slightly inflated, septa horizontal to slightly oblique, thickened and elevated. Wall perforate, elevated to beaded sutures, longitudinal costae.

Regional occurrence: Polish Carpathian Foredeep 'Moravian' (Langhian). 
Family Stilostomellidae Finlay, 1947

Genus Orthomorphina Stainforth, 1952

Orthomorphina columella (Karrer, 1877)

(Fig. 7 C)

1877 Nodosaria columella Karrer, p. 379, pl. 16, fig. 21. Material: About 10 specimens.

Description: Uniserial, elongate test, consisting of 5-7 ovate chambers; median chambers largest, first chamber rounded. Ultimate chamber small, with neck at terminal aperture. Chamber walls with thin costae perpendicular to sutures and extending over entire test. Sutures depressed.

Regional occurrence: Central Paratethys - early ‘Badenian' (Langhian). 